\title{
Characterization, isolation and cloning of sugarcane genes related to drought stress
}

\author{
Larissa Mara Andrade ${ }^{1 *}$, Thiago Romanos Benatti ${ }^{2}$, Paula M Nobile ${ }^{3}$, Maria Helena Goldman ${ }^{4}$, Antonio Figueira ${ }^{5}$, \\ Ana Lilia Alzate Marin ${ }^{6}$, Michael dos Santos Brito ${ }^{3}$, Jorge da Silva², Silvana Creste ${ }^{7}$ \\ From 5th Congress of the Brazilian Biotechnology Society (SBBIOTEC) \\ Florianópolis, Brazil. 10-14 November 2013
}

\section{Background}

Sugarcane is a major crop worldwide as raw material for sugar and ethanol production. Drought is one of the most limiting factor that affects sugarcane productivity. In order to understand the mechanisms of drought response, field and greenhouse assays were conducted with two droughtcontrasting sugarcane genotypes (IACSP94-2094/tolerant and IACSP97-7065/sensitive), and several genes up/downregulated under drought stress identified by microarrays and RNAseq analyses. Ten differential expressed genes in both assays were evaluated by qPCR [1], and three of them showed the transcriptional profile related drought tolerance: a- Lipoxygenase (ScLOX), acting in the biosynthesis of the jasmonic acid precursor, and recent studies showed their role in defense against drought stress [3]; b- Dehydrin, correlated to drought stress and associated to maintenance of turgor cells, [2]; c- Dirigent-jacalin, associated to resistance disease and abiotic stress tolerance [4] and also related to jasmonic acid, an important hormone on plant defense. These genes were chosen as target for functional analyses in rice and sugarcane transgenic plants.

\section{Methods}

The full-length sequences of the coded sequences of ScLOX, dehydrin and dirigent-jacalin genes were accessed by SMARTer RACE cDNA Amplification Kit (Clontech) using the tolerant genotype IACSP94-2094 mRNA. The cloning was performed using the vector pGEM-T Easy (Promega) and E. coli DH10B lineage. The clones were sequenced. After, the sequences were subcloned into pDONR 211 gateway vector and subsequently cloned in the overexpression and silencing

${ }^{1}$ Faculdade de Medicina de Ribeirão Preto/ Centro de Cana-IAC, Campinas, Brazil

Full list of author information is available at the end of the article vectors constructions to transformation plants via Agrobacterium.

\section{Results and conclusions}

The coding sequence of $S c L O X$ is incomplete at SUCEST (Sugarcane Functional Genomics Database). After many attempts of full-length transcripts ScLOX amplifications, only 3'RACE fragment from five clones were identified as the tag gene. On the other hand, the sequences from the 5'RACE amplification clones matched with others members from Lipoxygenase gene family. Nevertheless, the dehydrin and dirigent-jacalin were successful isolated and cloned as full-length coded sequences. From the 10 clones sequencing, it was found two allelic variant with a frameshift mutation and one as same identify of dehydrin sequences from the nucleotide databases queried. From 16 clones sequencing for dirigent-jacalin, it was found one allelic variant with frameshift mutation and one sequence matching the sequences from the database queried. The allelic variants, representing apparently nonfunctional alleles, were one of most difficulties in cloning the genes coded regions. This difficulty is attributed due the polyploidy and complexity genome of sugarcane. The allelic variant choice for the functional analysis was based on amino acid sequences alignment among sugarcane and related plants, e.g. rice, sorghum and maize, available in Phytozome and NCBI databases. The isolated coding sequences were engineered in plant overexpression and silencing construction vectors. Thereafter, rice and sugarcane embryogenic callus were transformed via Agrobacteriumtumefaciens and regenerated plants are under evaluation. The steps of identification, isolation and characterization of genes associated with response to stress are crucial for the development of transgenic plants improved for drought tolerance. 


\section{Acknowledgements}

Texas A\&M Agrilife, FAPESP, CNPq.

\section{Authors' details}

'Faculdade de Medicina de Ribeirão Preto/ Centro de Cana-IAC, Campinas, Brazil. ${ }^{2}$ Texas A\&M Agrilife Research and Extension Center, Dallas, TX, USA. ${ }^{3}$ LaFiMP - Depto. de Biologia Vegetal - IB - UNICAMP/ Centro de Cana-IAC, Campinas, Brazil. ${ }^{4}$ Faculdade de Filosofia de Ribeirão Preto, Brazil. ${ }^{5}$ Centro de Energia Nuclear na Agricultura, Piracicaba, Brazil. ${ }^{6}$ Faculdade de Medicina de

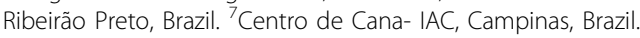

Published: 1 October 2014

\section{References}

1. Andrade LM, Peixoto-Junio RF, Nóbile PM, Brito MS, Nebó JF, Figueira A, Creste S: Validation of responsive genes to drought stress in two contrasting cultivars of sugarcane. Plant and Animal Genome, 11-16 January 2013; San Diego.

2. Cellier F, Conejero G, Breitler J-C, Casse F: Molecular and Physiological Responses to Water Deficit in Drought-Tolerant and Drought-Sensitive Lines of Sunflower. Accumulation of Dehydrin Transcripts Correlates with Tolerance Plant Physiol 1998, 116(1):319-328.

3. Ollas C, Hernando B, Arbona V, Gomez-Cadenas A: Jasmonic acid transient accumulation is needed for abscisic acid increase in citrus roots under drought stress conditions. Physiologia Plantarum 2012, 147:296-306.

4. Zhang WL, Peumans WJ, Barre A, Astoul CH, Rovira P, Rouge P, Proost $P$, Truffa-Bachi $P$, Jalali AA, Van Damme EJM: Isolation and characterization of a jacalin-related mannose-binding lectin from salt-stressed rice (Oryza sativa) plants. Planta 2000, 210:970-978.

doi:10.1186/1753-6561-8-S4-P110

Cite this article as: Andrade et al: Characterization, isolation and cloning of sugarcane genes related to drought stress. BMC Proceedings 2014 8(Suppl 4):P110

\section{Submit your next manuscript to BioMed Central and take full advantage of:}

- Convenient online submission

- Thorough peer review

- No space constraints or color figure charges

- Immediate publication on acceptance

- Inclusion in PubMed, CAS, Scopus and Google Scholar

- Research which is freely available for redistribution

Submit your manuscript at www.biomedcentral.com/submit 